\title{
Investigating Factors of Students' Competence in Internship Activity
}

\author{
N. Lestari, D. Meirawan, Ana \\ Graduate Program of Technology and Vocational Education \\ Universitas Pendidikan Indonesia \\ Bandung, Indonesia \\ nia_lestariabadi@yahoo.com
}

\begin{abstract}
This study aims to determine "the factors suspected to affect the competence of the authors work to limit to two variables: motivation and work attitude. The study took place in SMK Negeri 9 Bandung. Population in this research is the students who have done the work practices of the industry or internship, the number of members of the study sample totaled 52 people, sample testing of instruments made to students who have done internship outside the sample. This study using inferential method with quantitative approach. Data were collected through questionnaires, documentation, and testing. The raw data obtained later in the reduction, are summarized and grouped by category of existing and tested the validity, reliability, and hypothesis. Results of the study revealed that: (1) There is influence that significance between work motivation to work competence, among others include the interest in the work can be categorized as very good and perseverance in carrying out work practices, tenacity in working and sharpness of attention at work, a desire to excel in work practices, and independence in the following aspects of employment practices that are in the category of good. (2) There is no significant effect, work attitude toward work competence. Working attitude towards work competence include: be able to keep objects / equipment entrusted, aspects of the discipline in the form of attending regularly and on time, and obey the rules / regulations, liable to the task given, accept the risk of the action taken and maintaining and storing equipment / goods, cooperation be able to work together in groups, maintaining effective working relationships, and provide assistance and support to others, initiatives such as looking for new challenges, develop themselves and the opportunity to learn, and have an idea / action and innovative solutions. (3) work motivation and work attitude does not affect the competence of work.
\end{abstract}

Keywords-internship activity; student's competence

\section{INTRODUCTION}

The Central Statistics Agency (BPS) released the number of unemployed in August 2013 as many as 7.39 million people. Unemployment level Open (TPT) in August 2013 for vocational education occupies the highest position, and the lower level of elementary school education are at the lowest position is $3.51 \%$. TPT at all levels of education has decreased, but the level of vocational and high school education. This gap is caused by many factors, including vocational education carried out by schools that are less able to adapt to changes and developments in the world of work, so the job readiness of learners is still lacking. (Jefriando, 2013 in http://finance.detik.com).
Absorptive capacity of the tourism industry, especially hotels and restaurants for vocational graduates Tourism groups according to James in Ana (2008) are included in the category of very low. One of the problems in tourism development is the lack of adequate facilities to support tourism education workforce that is skilled, skilled, has a high skill and devotion in the field (professional) become an absolute necessity in global competition.

SMK Negeri 9 Bandung is SMK of Tourism in Bandung, which is considered successful. SMK Negeri 9 Bandung has a membership program that is of considerable interest Catering prospective students' junior high school graduates who are interested in continuing their education in vocational. Besides managed by professional management, these skills program also has a competent teaching staff and has attended various training and on the job training of tourism. The advantages possessed by the competence of this expertise is cooperation with some of the restaurant and hospitality industries both inside and outside the country, therefore students who choose this skill competency opportunity to follow the work practices in the industry's leading hotel. In addition, learners-learners elected in the competence of this expertise was given the opportunity to participate in an internship program or casual.

The authors made observations in order to trace the distribution of graduates based on data from relevant agencies as follows:

TABLE I. DATA DistribUtion GRADUATES HoSPITALITY BuSINESS SKILLS COMPETENCY SMK 9 BANDUNG IN 2011 AND 2013

\begin{tabular}{|c|c|c|c|c|c|c|c|}
\hline Year & Graduates & Independent & Working & Continue & $\begin{array}{l}\text { Working } \\
\text { is not }\end{array}$ & $\begin{array}{l}\text { not vet } \\
\text { recorded }\end{array}$ & $\begin{array}{l}\text { amount } \\
\text { of BMW }\end{array}$ \\
\hline 2011.2012 & 105 & $0.55 \%$ & $63.81 \%$ & $29.52 \%$ & $3.81 \%$ & $1.90 \%$ & \\
\hline 2012.2013 & 106 & $0.94 \%$ & $51.89 \%$ & $46.23 \%$ & $0.919 \%$ & $0.00 \%$ & $99.060 \%$ \\
\hline
\end{tabular}

Based on the table 1 it can be seen that graduates of SMK Negeri 9 Bandung has scored graduates who can work, Resume and Entrepreneurship (BMW), more than $50 \%$ of graduates who 
work in the appropriate field that is occupied positions at the Food and Beverage be it a product or service, The rest are graduates who have an independent business as well as continuing to Colleges, Polytechnics and Universities throughout Indonesia. The success of the system is run by SMK Negeri 9 Bandung is expected to be an example and a reference for other tourism sector in particular vocational Hospitality Business of learners in terms of job competence required by the World Business / Industrial World (DUDI). The researcher's intend to conduct research with the heading "Factors Affecting Work Competence of Students of SMK Negeri Tourism in Hotel and Restaurant Bandung".

\section{METHODS}

The method used is ex post facto, in which this study aims to investigate an event that has occurred and then observed to the rear of the factors that contributed to the incident. (Iskandar, 2009: p. 66). Sample in this study using a random sample of the students of SMK Negeri Tourism in Bandung, which has been doing industrial work practices, namely the students of class XII expertise Catering SMKN 9 Bandung. This study aims to determine the factors that affect the job competence of learners SMK Negeri Tourism in hotels and restaurants in Bandung using path analysis techniques. Techniques that I use in the collection of research data is in the form of a questionnaire given randomly to students of class XI (twelve) SMK in Bandung (Bandung SMKN 9) who are following the industry working practices (Internship) and documentation.

\section{RESULTS}

\section{A. Work Motivation (X1)}

Motivation to work in this study is the result of the questionnaire respondents vocational students. So a score of motivation is a reflection of motivation vocational students work in industry. To describe and know the description of work motivation vocational students Tourism State in the practice of industrial work students of SMK Negeri 9 Bandung, work motivation is translated into aspects 1) Perseverance in carrying out work practices, 2) The interest in the job, 3) tenacity in working and sharpness attention in the work, 4) the desire to excel in working practices, 5) following the independence in work practices.

Measurement of work motivation was conducted through a questionnaire. To measure motivation to work measuring instrument used was a questionnaire given to the respondents to each question item. Item questions in the questionnaire using a Likert scale 'always' (score 4), 'often' (score 3), 'sometimes' (score 2), 'never' (score of 1).

Scores for variables $\mathrm{X} 1$ and each of its aspects is calculated based on the scores ideal for those variables, i.e. 4-3-2-1 for positive statements and negative statements is 1-2-3-4. Based on data obtained from 52 respondents, the more likely the work motivation of learners is $74 \%$. These results are classified as 'good'.
Based on the above, the general supervisor DUDI respondents in this study perceived that professional competence is 'good enough'. Judging from the aspects as follows: 1) Perseverance in carrying out work practices, 2) The interest in the job, 3) tenacity in working and alertness at work, 4) the desire to excel in working practices, 5) independence in following work practices, then work motivation can be described as follows:

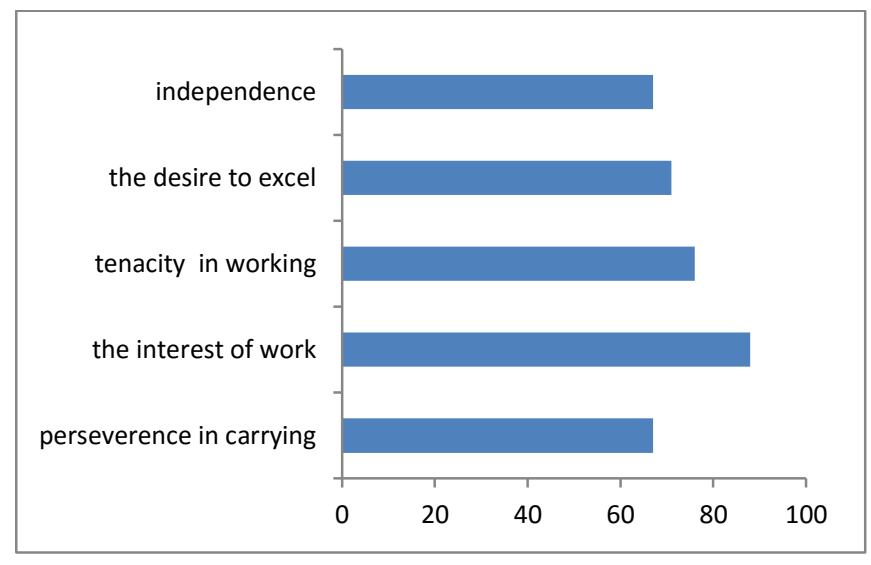

Fig. 1. The professional competencies of student's

Judging from the average value, achievement of work motivation variable score is $74 \%$, which is classified into the category of fairly good $(56 \%-65 \%)$. Achievement of the average scores of each aspect categorized as 'very good', namely: interest in work (88\%), the rest are in the category of 'good', namely the aspect: perseverance in carrying out the work practices $(67 \%)$, tenacity in working and sharpness of attention in work $(76 \%)$, the desire to excel in working practices $71 \%$, and independence in following work practices (67\%).

Based on the table, the level of work motivation of learners are most common in both categories is $80 \%$. While the remaining $20 \%$ of students have a very good level of motivation.

\section{B. Work Attitude (X2)}

Work attitude competency is the ability of non-technical aspects that form the components that play a supportive successfully learners to improve their skills and interaction the environment in which internship. To describe and know the description of the work attitude of learners SMK Negeri Tourism in Hotel and Restaurant Bandung, variable attitudes of this work translated into aspects 1) Honest, 2) Discipline, 3) Responsibility, 4) Cooperation, 5) initiative.

Work attitude measurement is conducted through a questionnaire. Item questions using a scale attitude 'always' (score 4), 'often' (score 3), 'sometimes' (score 2), 'never' (score of 1). Scores for X2 and each aspect is calculated based on the scores ideal for those variables, namely 26 items $\times 52$ respondents $\mathrm{x} 4$ (the highest score for each item) $=5,408$. Total score obtained is 4953 . So based on data obtained from 52 respondents, the perceived tendency of working attitude is the $4953 / 5408 \times 100 \%=91.5 \%$. 


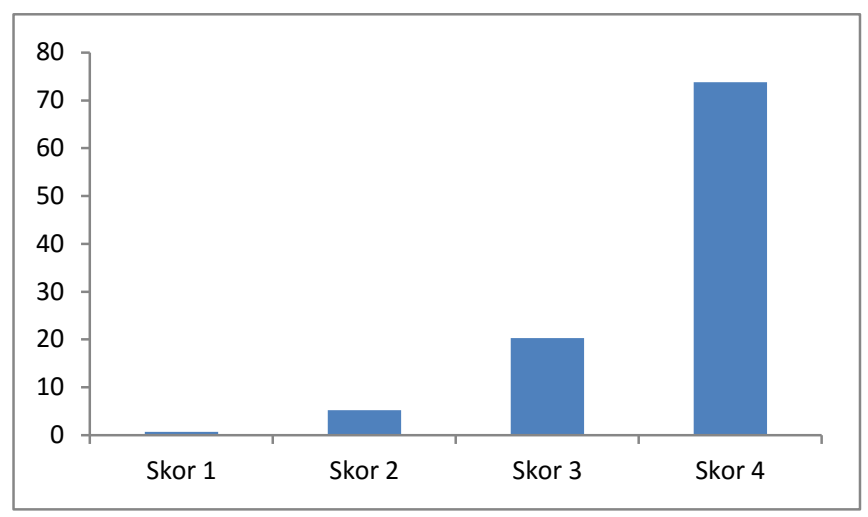

Fig. 2. Percentage Distribution of Score Answer Respondents Variable 52 X2

Based on the Fig. 2, in general, vocational school students who were respondents in this study perceive that having a working attitude is 'very good'. Seen from these aspects, namely: 1) Honest, 2) Discipline, 3) Responsibility, 4) Cooperation, 5) initiative, the work attitude can be described as follows:

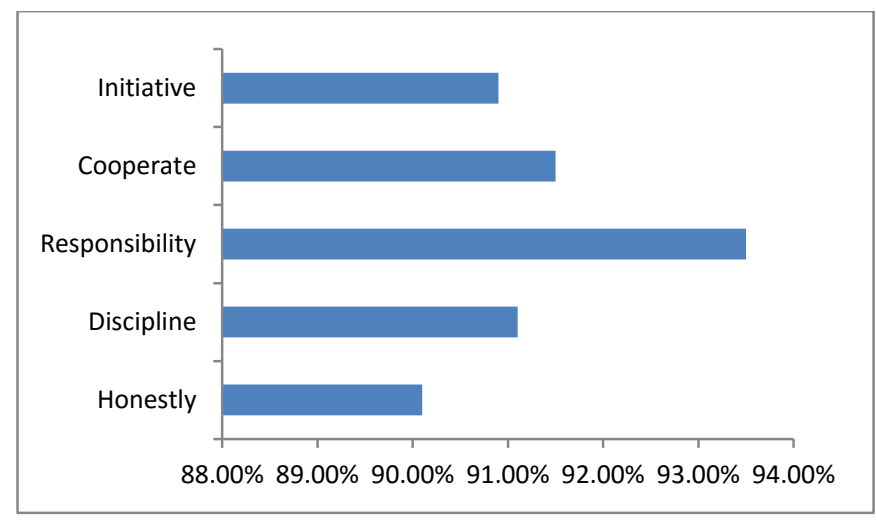

Fig. 3. Overview Variable X2 and achievement-aspect Aspects

Judging from the average score (scale up to 4), the achievement scores of variables working attitude is $91.5 \%$ which is classified into the category very well. Achievement of the average scores of each aspect included into the category of 'very high', ie honest $(90.1 \%)$, discipline $(91.1 \%)$, responsible $(93.5 \%)$, cooperation $(91.5 \%)$, initiative $(90.9 \%)$.

\section{Work Competence}

Competence of work in this research is the result of the test vocational students. So the score is a reflection of the work competency attainment of vocational students work in industry. To describe and know the description of work competence of vocational students in the State Tourism industry students of SMK Negeri 9 Bandung, job competency variable is translated into aspects 1) Preparation work, 2) process, 3) Work, 4) working attitude, 5) Time.
Measurement is done through the work competency tests. To measure job competence measuring instruments used are tests given to the respondents in each component of the assessment, the tests carried out in the form of competency practice tests with assessment of competence achievement using a nominal scale $<7.0$ to 10

Scores for variable $\mathrm{Y}$ and each aspect is calculated based on the scores ideal for those variables, namely 5 items x $100 \times 52$ respondents (score component achievement of competence) $=$ 26,000. Total score obtained is 23 007. So based on data obtained from 52 respondents, the more likely perceived job competence is $23007 / 26,000 \times 100 \%=88.48 \%$. This result is 'very good'.

The author in this study perceive that the competence of labor is 'very good'. Judging from the aspects as follows: 1) aspect 1) Preparation work, 2) process, 3) Work, 4) working attitude, 5) Time. Then the job competence of learners can be described as follows:

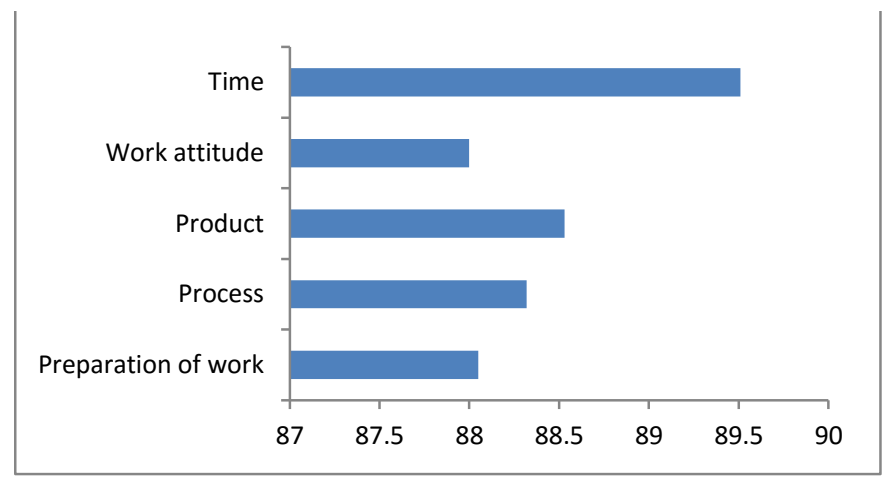

Fig. 4. Overview Variable Y and achievement-aspect Aspects

Judging from the average value, achievement of job competence variable score is $88.48 \%$, which is classified into the category of very good $(80 \%-100 \%)$. Achievement of the average scores of each aspect categorized as 'very good', namely: able to carry out preparatory work in the form of tools, materials, and work clothes $(88.05 \%)$, capable of performing the work process in the form of systematic, ways of working, and the arrangement of the display table (88.32\%), capable of displaying the work in the form of product / dish (shape, color, texture, temperature, taste, creativity), displays, and packaging $(88.53 \%)$, able to demonstrate work attitude tool use, sanitation, and applying K3 (88 \%), and time (accuracy in completing the practice exam $(89.51 \%)$.

\section{DISCUSSION}

A. Description of Work Motivation of Students of SMK Negeri Tourism in Hotel and Restaurant Bandung

Based on the aspect of work motivation in activities internship note that motivation of learners SMK Negeri Tourism in hotels and restaurants in Bandung through questionnaires generally categorized as 'good'. This is caused by the interest of learners in doing the work assigned by the supervisor. 
For details of the achievements of the average scores of each aspect categorized as 'very good', namely: interest in the job. Aspects that are in the category of 'good', namely the aspect: perseverance in carrying out work practices, tenacity in working and sharpness of attention at work, a desire to excel in working practices, and independence in following work practices. In the description of the calculation results of the motivation to work in internship activity can be explained as follows:

1) Most respondents perceive that in carrying out the necessary work in practice perseverance can be present in the workplace, and feel the loss if it does not make working practices.

2) Most respondents perceive that perseverance in carrying out such work following the working practices in accordance with the assigned job.

3) Most respondents perceive that in doing the work, interest in the job is very important because students always learn and continue to relearn the material related to the task of practice.

4) Most respondents perceive that in doing the work in a tenacity in working internship important to discipline yourself so as not slacking off at work.

5) Most respondents perceive that tenacity in working able to be challenged in new tasks.

6) Most respondents perceive that the tenacity and sharpness reflect in their work, inability to concentrate attention to job duties and understand an instruction of a given task supervisor.

7) Most respondents perceive that in doing the work in practice, is able to achieve and receive work no matter how the results of achievement.

8) Most respondents perceive that in understanding the principles of self-reliance in following work practices, capable of independent business in following work practices such as trying to do the work on their own and learn workrelated references in internship Sukmadinata (2003, p. 61) suggested that the motivation is the "force that drives an individual activity, which indicates a condition within the individual who encourages or directs the activities of individuals reach a goal". Individual behavior does not stand alone, there are always things that pushed and fixed on a goal to be achieved. Objectives and factors driving this may be realized by the individual, but maybe not, something concrete or abstract.

\section{B. Description of Work Attitude of Students of SMK Negeri Tourism in Hotel and Restaurant Bandung}

Based on the aspect variable working attitude in the activities internship in hotels and restaurants is known that the work attitude of learners SMK Tourism State in hotel and restaurant Bandung through questionnaires students are generally categorized as 'very good', be able to keep objects / equipment entrusted, aspects of the discipline in the form of attend regularly and on time, and obey the rules / regulations, liable to the task given, accepts the risk of actions taken, and maintaining and storing equipment / goods, cooperation be able to work together in groups, maintaining relationships effective work, and provide assistance and support to others, initiatives such as looking for new challenges, develop themselves and the opportunity to learn, and have an idea / action and innovative solutions.

In the description of the calculation results of the work attitude in the process internship activity can be explained as follows:

1) Most respondents perceive that the workers who have working attitude is honest, who always keeps his trust to the task whether it be tools or data.

2) Most respondents perceive that discipline is an effort to adhere to the rules / regulations and carry out the work according to established procedures.

3) Most respondents perceive that responsibility in carrying out the tasks assigned to the bitter end, and do not leave a job with the work load to a colleague / others, and is able to accept the risk of the action taken.

4) Most respondents perceive that work is influenced by the attitude of cooperation and maintain effective working relationships with colleagues.

5) Most respondents perceive that the initiative was to develop themselves and have ideas / solutions that are innovative, capable new challenges, develop themselves in work to improve job skills and MAMP respond quickly to the situation and changes in the environment.

\section{Description of Work Motivation and Job Attitudes toward Work Competence}

Based on the hypothesis test is known that there is a positive and significant influence between motivation and work attitudes toward work competence of learners SMK Negeri in hotels and restaurants in Bandung. Test the hypothesis by using the technique of path analysis (path analysis) with the help of SPSS 16.0 was obtained value of the regression line of work motivation (X1) and work attitudes (X2) on work competency is a number $\mathrm{R}$ obtained 0.227 means that the correlation between the variables of motivation and work attitudes toward competence work does not happen very close relationship because the value of R is not close to 1 . Value of R Square (R2) of 0.052 means the percentage contribution of the effect of work motivation and work attitudes toward work competence of $5.2 \%$. While the calculated $\mathrm{F}$ value of 1.336 at a significance level of 0.05 with $1 \mathrm{df}=2$ and df $2=52-2-1=49$, the results obtained for the F table 3.187. Since F arithmetic <F table $(1.336<3.187)$ then $\mathrm{HO}$ is accepted so it can be concluded that the motivation and work attitude does not affect the competence of work.

Competence in work is the ability to behave, think and act consistently as the embodiment of knowledge, attitudes, and skills possessed. In the world of work competency is "an underlying characteristic of an individual that is casually related to criterion-referenced effecting and / or superior performance in a job situation" means the underlying characteristics of individuals associated with the criteria that affect superior performance in a job situation. 
Work competence is closely related to labor productivity. Homage there are many factors that affect, among others, work motivation. Natsir (2005, p 45) in research states that "the effect of work motivation on employee performance discussion is significant".

Secord and Backman (in Anwar, 2012, p. 5) defines attitude as "a certain regularity in terms of feelings (affection), thinking (cognition), and predisposition action a person against aspects of the surrounding environment". A person's success can also be affected by his attitude in interacting with the environment, particularly in this case is the work environment. Agustian (2002) in Majid \& Andayani (2011, p. 43), there are seven basic character that determines a person's success, namely: 1) honest, 2) responsibility, 3) discipline, visionary, 5) fair, 6) concerned, 7 ) cooperation.

This study provides the conclusion that partial motivation to work has contributed significantly to job competence, and the rest influenced by other variables.

\section{CONCLUSION}

1. Description of Work Motivation of Students of SMK Negeri Tourism in Hotel and Restaurant Bandung.

a. Most respondents perceive that in carrying out the necessary work in practice perseverance can be present in the workplace, and feel the loss if it does not make working practices.

b. Most respondents perceive that perseverance in carrying out such work following the working practices in accordance with the assigned job.

c. Most respondents perceive that in doing the work, interest in the job is very important because students always learn and continue to relearn the material related to the task of practice

d. Most respondents perceive that in doing the work in a tenacity in working internship important to discipline yourself so as not slacking off at work

e. Most respondents perceive that tenacity in working able to be challenged in new tasks.

f. Most respondents perceive that the tenacity and sharpness reflect in their work, inability to concentrate attention to job duties and understand an instruction of a given task supervisor.

g. Most respondents perceive that in doing the work in practice, is able to achieve and receive work no matter how the results of the achievements.

h. Most respondents perceive that in understanding the principles of self-reliance in following work practices, capable of independent business in following work practices such as trying to do the work on their own and learn work-related references in internship.
2. Description of Work Attitude of Students of SMK Negeri Tourism in Hotel and Restaurant Bandung.

a. Most respondents perceive that the workers who have working attitude is honest, who always keeps his trust to the task whether it be tools or data.

b. Most respondents perceive that discipline is an effort to adhere to the rules / regulations and carry out the work according to established procedures.

c. Most respondents perceive that responsibility in carrying out the tasks assigned to the bitter end, and do not leave a job with the work load to a colleague / others, and is able to accept the risk of the action taken.

d. Most respondents perceive that work is influenced by the attitude of cooperation and maintain effective working relationships with colleagues.

e. Most respondents perceive that the initiative was to develop themselves and have ideas / solutions that are innovative, capable new challenges, develop themselves in work to improve job skills and MAMP respond quickly to the situation and changes in the environment.

3. Description of Work Motivation and Job Attitudes toward Work Competence.

a. This study provides the conclusion that partial motivation to work has contributed significantly to job competence, and the rest influenced by other variables.

\section{REFERENCES}

[1] Aina, Ita Dewi Nur dan Isroah. 2012. Pengaruh Minat Memilih Keahlian dan Praktik Industri terhadap Kesiapan Kerja Siswa SMK Kelas XI Akuntansi SMK Negeri Sleman Tahun Ajaran 2011/2012. eJournal Universitas Negeri Yogyakarta. Vol 2 (2) dalam: http://journal.student.uny.ac.id/ jurnal/artikel/2284/44/302

[2] Akdon dan Riduwan. (2006). Rumus dan Data dalam Aplikasi Statistika. Bandung: Alfabeta.

[3] Andoko. 2010. Potret Motivasi Kerja dengan Kesiapan Kerja Siswa SMK Kota Malang. Jurnal Teknik Mesin. Vol.16 (1).

[4] Anggoro. T. (2007). Metode Penelitian. Jakarta. Universitas Terbuka.

[5] Arikunto, Suharsimi. 2002. Prosedur Penelitian Suatu Pendekatan Praktek. Jakarta: PT Rineka Cipta.

[6] Badeni. 2002. "Relevansi SMK Berpendidikan Sistem Ganda (PSG) dengan Kebutuhan Pasar Kerja di Indonesia'. Jurnal Pendidikan dan Kebudayaan. Jakarta. Edisi September Tahun ke 8 No. 038. 710-725.

[7] Brady, Robert P. (2009) “ Work Readiness Inventory Administrastartor's Guide". Jurnal diambil dari http://www.jist.com/shop/web/workreadiness inventory administrator guide.pdf. Diakses tanggal 25 Maret 2014.

[8] Depdikbud. 1999. Pedoman Peiaksanaan Kurikulum Sekolah Menengah Kejuruan. Jakarta:

[9] Depdikbud. Depdiknas. 2004. Kurikulum SMK Edisi 2004. Jakarta: Depdiknas.

[10] Dirwanto. 2008. Analisis Faktor-faktor yang Mempengaruhi Kesiapan Kerja pada Siswa SMK Ma'arif NU Kesesi Kabupaten Pekalongan Tahun Pelajaran 2007/2008. http://eprints.uns.ac.id/10302/1/75002003201207471.pdf diakses tanggal 3 Februari 2014 
[11] Hamalik, Oemar. 1990. Pendidikan Tenaga Kerja Nasional Kejuruan, Kewiraswastaan dan Manajemen. Bandung: Citra Aditya Bakti.

[12] Hasbullah, 1997. Dasar-dasar Ilmu Pendidikan. Jakarta: P.T. Raja Grafindo Persada.

[13] Joyoatmojo, Soetarno. 2003. Pembelajaran Efektif: Upaya Peningkatan Kualitas Lulusan Menuju Penyediaan Sumber Daya Insani yang Unggul. Pidato Pengukuhan Guru Besar Fakultas Keguruan dan Ilmu Pendidikan Universitas Sebelas Maret. Surakarta: UNS Press.

[14] Mardalis. 2002. Metode Penelitian Suatu Pendekatan Proposal. Jakarta: Bumi Aksara.

[15] Masyuri dan Zainuddin, M. (2008). Metodologi Penelitian Pendekatan Praktis dan Aplikatif. Bandung: PT. Refika Aditama

[16] Mudyahardjo, Redja. 2002. Pengantar Pendidikan Sebuah Studi Awal tentang Dasar-dasar Pendidikan pada Umumnya dan Pendidikan di Indonesia. Jakarta: PT Raja Grafindo Persada.

[17] Mulyasa, E. 2003. Kurikulum Berbasis Kompetensi Konsep, Karakteristik, dan Implementasi. Bandung: PT Remaja Rosdakarya.

[18] Muyasaroh, dkk. (2013). Pengaruh Pengalaman Praktik Kerja Industri dan Locus Control Terhadap Kesiapan Kerja Siswa Kelas XII SMK Negeri Surakarta. Jurnal Pendidikan Ekonomi (JUPE) UNS. 1 (1). Pp. 1-11.

[19] Narbuko, C. 2004. Metode Penelitian. Jakarta:PT. Bumi Aksara

[20] O Brien, et al. 2012. Work Readiness of Final-year Civil Engineering Student at Victoria University: A Survey. Jornal of Engineering Education. 18 (1).

[21] Ruky, Achmad S.. 2003. Sumber Daya Manusia Berkualitas Mengubah Visi Menjadi Realitas. Jakarta: PT Gramedia Pustaka Utama.

[22] Schunk, Dale H., Pintrich, Paul R., \& Meece, Judith L. 2008. Motivation in Education; Theory, Research, and Applications, Third Edition. New Jersey: Pearson Education Inc.

[23] Setiadi, Nugroho J.. 2005. Perilaku Konsumen Konsep dan Implikasi uniukStrategi dan Penelitian Pemasaran, Jakarta: Kencana.
[24] Sofyan, Herminanto. 1992. Kesiapan Kerja Siswa STM di Jawa. Laporan Penelitian. Yogyakarta: IKIP Yogyakarta.

[25] Sugiono. (2008). Metode Penelitian Pendidikan. Bandung: Alfabeta

[26] Soeprijanto. 2010. Daya Dukung Dunia Industri terhadap Praktik Kerja Industri (Internship). Jurnal Pendidikan dan Kebudayaan. 6 (3). Pp. 275 284

[27] UU RI No. 20 Tahun 2003 tentang Sistem Pendidikan National. Jakarta Depdiknas.

[28] UU RI No. 13 Tahun 2003 tentang Ketenagakerjaan. Jakarta: Depnakertrans.

[29] Yusuf, Muri A. 2002. Kiat Sukses dalam Karier. Jakarta: Ghalia Indonesia. Jurnal

[30] Narti, Ni Ketut. Pengaruh Motivasi dan Praktik Kerja Lapangan serta Sarana Pembelajaran Praktik terhadap Kesiapan Kerja Mahasiswa Jurusan Pariwisata Politeknik Neeri Bali pada Sektor Industri Pariwisata.

[31] Gustimulya, dkk. 2012. Korelasi Pelaksanaan Praktik Kerja Industri (Internship) dan Motivasi Kerja terhadap Kesiapan Kerja Memasuki Dunia Kerja Siswa SMK Negeri 1 Batam

[32] Hastuti, Sri Rahayu dkk. 2012. Hubungan Hasil Belajar Produktif dan Internship dengan Kesiapan Kerja Siswa SMK di Kabupaten AGAM

[33] Astuti, Erma Dwi. 2012. Pengaruh Pengalaman Praktik Kerja Industri dan Prestasi Belajar terhadap Kesiapan Kerja Siswa Kelas XII Program Keahlian Akuntansi SMK YPKK 1 Sleman.Internet

[34] Ana. 2008. Problematika Lulusan SMK Pariwisata di Industri Pariwisata Jasa

[35] Boga. [online] Tersedia di: http:/file.upi.edu. Diakses tanggal 18 Maret 2014

[36] Jefriando, Maikel. 2013. Pengangguran Paling Banyak dari Tamatan SMK. Tersedia di: http://finance.detik.com/ [online]. Diakses tanggal 18 Maret 2013.

[37] http://www.nakertrans.go.id, 14 Desember 2006

[38] http://www.wikarya.net, 14 Desember 2006 